African Crop Science Journal by African Crop Science Society is licensed under a Creative Commons Attribution 3.0 Uganda License. Based on a work at www.ajol.info/ and www.bioline.org.br/cs DOI: http://dx.doi.org/10.4314/acsj.v24i4.1

\title{
EFFECTS OF SERIAL PLANTING OF SEED YAM TUBERS ON VIRUS INCIDENCE AND YAM TUBER DEGENERATION
}

\author{
S.W. ASALA ${ }^{1,3}$ and M.D. ALEGBEJO ${ }^{2}$ \\ ${ }^{1}$ Department of Crop Science, Faculty of Agriculture, University of Abuja, Abuja, Nigeria \\ ${ }^{2}$ Department of Crop Protection, Faculty of Agriculture, Ahmadu Bello University, Zaria, Nigeria \\ ${ }^{3}$ International Institute of Tropical Agriculture, PMB 5320, Ibadan, Nigeria \\ Corresponding author: shatuasala@yahoo.com
}

(Received 30 March, 2015; accepted 3 November, 2016)

\begin{abstract}
Vegetative propagation of yam (Dioscorea spp.) with seed tubers is done to ensure uniformity of crop growth and yield. The objective of this study was to evaluate the effect of serial planting of seed yam on virus incidence and tuber degeneration in the Southern Guinea Savanna agro-ecologies of Nigeria. This study was conducted during the wet seasons of 2010 to 2012 at Kwara State and Abuja Federal Capital Territory (Abuja-FCT) in Nigeria. TDa 05/00129 and TDr 89/02665 yam bred lines from the International Institute of Tropical Agriculture, Ibadan, and three popular local varieties from each of Kwara State and Abuja Federal Capital Territory (AbujaFCT) were used in the study. Harvested seed yams were tested for Yam mosaic virus (YMV), Yam mild mottle virus (YMMV), Dioscorea alata bacilliform viruses (DaBV) and Cucumber mosaic virus (CMV). Data obtained for germination percentage, virus incidence and tuber yields were subjected to ANOVA with mean separation done using Tukey HSD method in SPSS version 24. Viruses YMV, YMMV and DaBV were detected in seed yam as single or mixed infections. High virus incidence was associated with low tuber yield while low virus infection was associated with high tuber yield for most yam varieties. However, TDa 05/00129 produced high tuber yield inspite of high incidence of viruses in the tubers, indicating adaptation of this variety. There was progressive increase in virus population in yam seeds from the first to the third year of study with concurrent degeneration of seed yam and low yield at harvest.
\end{abstract}

Key Words: Propagation, serial, Southern Guinea, vegetative

\section{RÉSUMÉ}

La multiplication végétative de l'igname (espèces de dioscorea) avec des tubercules de graine est faite pour assurer l'uniformité de la croissance de culture et pour rapporter. L'objectif de cette étude était d'évaluer l'effet de la plantation périodique de l'igname de graine sur la dégénérescence d'incidence et de tubercule de virus en agroécologie du sud de la savane de la Guinée du Nigéria. Cette étude a été entreprise pendant les saisons des pluies de 2010 à 2012 à l'état de Kwara et au territoire capital fédéral d' Abuja (Abuja-FCT) au Nigéria. TDa 05/00129 et TDr 89/02665 igname multipliée raye de l'institut international de l'agriculture tropicale, Ibadan, et trois variétés locales populaires de chacun de l'état de Kwara et du territoire capital fédéral d'Abuja (Abuja-FCT) ont été employées dans l'étude. Des ignames moissonnées de graine ont été examinées virus pour le virus doux du virus de mosaïque d'igname (YMV), virus ignifuge de l'igname (YMMV), les virus bacilliformes de dioscorea alata (DaBV) et de concombre mosaïque (CMV). Des données obtenues pour le pourcentage de germination, l'incidence de virus et les rendements de tubercule ont été analysées utilisant ANOVA avec la méthode moyenne de Tukey HSD de séparation dans la version 24 de SPSS. Des virus YMV, YMMV et DaBV ont été détectés en igname de graine en tant qu'infections simples ou mélangées. L'incidence élevée de virus a été associée au bas 
rendement de tubercule tandis que la basse infection de virus était associée au rendement élevé de tubercule pour la plupart des variétés d'igname. Cependant, TDa 05/00129 a produit le rendement élevé de tubercule malgré l'incidence élevée des virus dans les tubercules, indiquant l'adaptation de cette variété. Il y avait augmentation progressive de population de virus pendant graines d'igname dès la début à la troisième année d'étude avec la dégénérescence concourante de l'igname de graine et du bas rendement à la récolte.

Mots Clés: Propagation, périodique, Guinée du sud, végétatif

\section{INTRODUCTION}

Arising from the continued and increasing dependence on yam (Dioscorea spp.) for food in Nigeria, and considering its importance for food security, farmers are continually boosting the diversity of their plots by domesticating high yielding varieties and world species (Dumont and Vernier, 2000). Viral diseases are known to affect yam, not only in terms of productive capacity, but also limitations in international trade of the commodity. Nigeria is the world's largest producer of yam, yet it suffers rejection in world market due to failure to satisfy quarantine regulations (Ng, 1992; Okoroafor, 2009).

Diseases caused by viruses, fungi, nematodes and bacteria, either singly or in combination contribute greatly to yield and tuber quality losses (Hughes et al., 1997; Kapinga et al., 2005). Viruses are of particular concern because they cause disqualification of germplasm for international exchange.

Yam viruses exist in most yam growing areas of West Africa (Phillips et al., 1999; Odu, 2002; Asala et al., 2012). These include Yam mosaic virus (YMV) Genus Potyvirus, Yam mild mottle virus (YMMV) Genus Potyvirus, Diosocrea dumetorum virus (DdV) Genus Potyvirus, Dioscorea alata bacilliform virus (DaBV) Genus Badnavirus, Dioscorea sansibarensis virus (DSBV) Badnavirus, Cucumber mosaic virus (CMV) Genus Cucumovirus and Dioscorea mottle virus (DMoV) Genus Comovirus (Njukeng et al., 2002; Atiri et al., 2003). Studies in West Africa revealed the presence of viral infections in the Dioscorea species from Nigeria, Togo and Ivory Coast (Mohammed and Terry, 1979; Thouvenel and Fauquet, 1979; Rossell and Thottappilly, 1985; Odu et al., 2006; Asala et al., 2012). Osmond (2006) reported that yam mosaic virus has a wide spread distribution in West Africa. The virus has also been found to occur in regions of Guadeloupe and Guyana (Migliori and Cadihac, 1976). Yam propagation is done vegetatively using seed tubers a practice that can lead to build up of viral infections and degeneration of the crop due to repeated use of seeds from the same line (Bodoni and Chanhan, 2009). The objective of this study was to assess the effect of repeated planting of seed yam on virus infection and tuber yield in the Guinea Savanna zone of Nigeria for which data is not available.

\section{MATERIALS AND METHODS}

This study was conducted in the wet seasons of 2010 to 2012. Field trials were organised in a randomised complete block design (RCBD) in 30 $\mathrm{m}^{2}$ plots. Yam varieties used included TDa 05/ 00129 and TDr 89/02665 cultivars from IITA and three popular local varieties from each of Kwara State (Gbakunmo, Elemsu and Orin) and Abuja Federal Capital Territory (Makakusa, Dan-anachia and Army). The first trials in 2010 were planted in one location each in Kwara and Abuja FCT. Harvested seed yams from these trials were used for second season planting in 2011. The seed yams harvested from the second trials were again used for the third year planting. The germination percentage was recorded for each of the trial years.

At the end of each growing season, the harvested yam tubers were weighed. The tubers were tested for the presence of Yam mosaic virus, Yam mild mottle virus and Badnavirus commonly present in yam tubers in the trial sites (Asala $e t$ al., 2014).

The tests employed Polymerase Chain Reaction (PCR) technique, using appropriate primers and protocol (Mumford and Seal, 1997; Seal and Muller, 2007). Extracts from known virusfree yam leaves were used for the negative control, while extracts from known virus-infected 
plants were used as positive control for each reaction set up in the PCR. The viruses present were quantified and the incidence was expressed in percentages.

Data obtained for germination percentage, virus incidence and tuber yields were initially analysed using ANOVA while means were separated with Tukey HSD method, resident in SPSS version 24 .

\section{RESULTS}

Types and Incidence of Virus in yam tubers. In the first year (2010) of trial the tuber seeds tested positive to Yam Mosaic Virus (YMV) only (Table 1). In 2011, YMV and Badnavirus (DaBV) were detected in the tubers either singly or in mixed infection. In 2012, YMV, DaBV and Yam Mild Mottle Virus (YMMV) were detected in all treatments in single and mixed infections (Table 1).

The year 2010, recorded the lowest percentage incidence of virus in seed tubers. Viruses were not detected in seed of varieties Army and Dan-anachia in the first year of study but YMV and Badnavirus were detected in the following years. The year 2012 recorded the highest incidence of virus of up to $100 \%$ in yam seeds (Table 1).

Interaction of yam varieties, location and year with measured variables. Table 2 shows that between the locations, only the tuber yield showed statistically significant difference at $\mathrm{P}<0.05$. For the years of planting, germination, virus incidence and tuber yield showed statistically significant differences. The interactions of location and year and location and variety with germination and yield were significant. For location, year and variety, the interactions with germination and yield were significant (Table 2).

Germination of planted yam tubers. Table 3 shows that the germination of Orin from Kwara State is significantly lower than all other yam varieties except Elemsu. The variety TDa 05/ 00129 from Kwara recorded the highest yield which is not significantly higher than that of TDa 05/00129 from Abuja and TDr 89/02665 from Kwara State (Table 3).

TABLE 1. Types of viruses and Virus Incidence in yam tubers in Abuja Federal Capital Territory and Kwara State Nigeria

\begin{tabular}{|c|c|c|c|c|c|c|}
\hline \multirow[t]{3}{*}{ Yam varieties and locations } & \multicolumn{6}{|c|}{ Types and Incidence of viruses detected in tuber by PCR } \\
\hline & \multicolumn{2}{|c|}{2010} & \multicolumn{2}{|c|}{2011} & \multicolumn{2}{|c|}{2012} \\
\hline & $\begin{array}{c}\text { Type of } \\
\text { virus }\end{array}$ & $\begin{array}{c}\text { Incidence } \\
(\%)\end{array}$ & $\begin{array}{r}\text { Type of } \\
\text { virus }\end{array}$ & $\begin{array}{c}\text { Incidence } \\
(\%)\end{array}$ & $\begin{array}{c}\text { Type of } \\
\text { virus }\end{array}$ & $\begin{array}{c}\text { Incidence } \\
(\%)\end{array}$ \\
\hline \multicolumn{7}{|c|}{ Abuja Federal Capital Territory } \\
\hline TDr 89/02665 & Y & 3.3 & $Y, B$ & 20.0 & $Y, Y^{M}$ & 96.0 \\
\hline TDa 05/00129 & Y & 3.3 & $Y, B$ & 26.7 & $\mathrm{~B}$ & 92.9 \\
\hline Makakusa & Y & 10.0 & B & 30.0 & $Y, B$ & 100.0 \\
\hline Army & Nil & 0.0 & $Y, B$ & 20.0 & $Y, B$ & 100.0 \\
\hline Dan-anachia & Nil & 0.0 & $\mathrm{~B}$ & 20.0 & $\mathrm{Y}, \mathrm{B}$ & 96.0 \\
\hline \multicolumn{7}{|l|}{ Kwara State } \\
\hline TDr 89/02665 & $Y$ & 3.3 & $Y, B$ & 20.0 & $Y, B$ & 86.4 \\
\hline TDa 05/00129 & $Y$ & 6.7 & $\mathrm{Y}, \mathrm{B}$ & 30.0 & $B$ & 40.0 \\
\hline Gbakumo & $Y$ & 6.7 & $Y, B$ & 23.3 & B & 88.2 \\
\hline Orin & $Y$ & 13.3 & $Y, B$ & 36.7 & $B$ & 50.0 \\
\hline Elemsu & $Y$ & 20.0 & $Y, B$ & 43.3 & B & 87.5 \\
\hline
\end{tabular}

$\mathrm{Y}=$ Yam mosaic virus, $\mathrm{Y}^{\mathrm{M}}=$ Yam mild mottle virus, $\mathrm{B}=$ Badnavirus, $\mathrm{PCR}=$ Polymerase Chain Reaction 
TABLE 2. Interaction of location, year and variety with measured variables in Abuja and Kwara State

\begin{tabular}{|c|c|c|c|c|c|c|}
\hline Source & Dependent variable & $\begin{array}{l}\text { Sum of } \\
\text { squares }\end{array}$ & Df & $\begin{array}{l}\text { Mean } \\
\text { square }\end{array}$ & $\mathrm{F}$ & Sig. \\
\hline Location & $\begin{array}{l}\text { Germination (\%) } \\
\text { Virus incidence (\%) } \\
\text { Yield }\end{array}$ & $\begin{array}{r}250.000 \\
6.724 \\
1975.899\end{array}$ & $\begin{array}{l}1 \\
1 \\
1\end{array}$ & $\begin{array}{r}250.000 \\
6.724 \\
1975.899\end{array}$ & $\begin{array}{r}1.607 \\
.060 \\
56.832\end{array}$ & $\begin{array}{l}.210 \\
.808 \\
.000^{*}\end{array}$ \\
\hline Year & $\begin{array}{l}\text { Germination (\%) } \\
\text { Virus incidence (\%) } \\
\text { Yield }\end{array}$ & $\begin{array}{r}7335.556 \\
1094.118 \\
571.840\end{array}$ & $\begin{array}{l}2 \\
2 \\
2\end{array}$ & $\begin{array}{r}3667.778 \\
547.059 \\
285.920\end{array}$ & $\begin{array}{r}23.579 \\
4.841 \\
8.224\end{array}$ & $\begin{array}{l}.000^{*} \\
.011^{*} \\
.001^{*}\end{array}$ \\
\hline Variety & $\begin{array}{l}\text { Germination (\%) } \\
\text { Virus incidence (\%) } \\
\text { Yield }\end{array}$ & $\begin{array}{r}15528.889 \\
478.006 \\
6616.504\end{array}$ & $\begin{array}{l}4 \\
4 \\
4\end{array}$ & $\begin{array}{r}3882.222 \\
119.502 \\
1654.126\end{array}$ & $\begin{array}{r}24.957 \\
1.058 \\
47.577\end{array}$ & $\begin{array}{l}.000^{*} \\
.385 \\
.000^{*}\end{array}$ \\
\hline Location + year & $\begin{array}{l}\text { Germination (\%) } \\
\text { Virus incidence (\%) } \\
\text { Yield }\end{array}$ & $\begin{array}{r}14286.667 \\
487.009 \\
330.583\end{array}$ & $\begin{array}{l}2 \\
2 \\
2\end{array}$ & $\begin{array}{r}7143.333 \\
243.504 \\
165.291\end{array}$ & $\begin{array}{r}45.921 \\
2.155 \\
4.754\end{array}$ & $\begin{array}{l}.000^{*} \\
.125 \\
.012^{*}\end{array}$ \\
\hline Location + variety & $\begin{array}{l}\text { Germination (\%) } \\
\text { Virus incidence (\%) } \\
\text { Yield }\end{array}$ & $\begin{array}{r}4755.556 \\
127.007 \\
850.981\end{array}$ & $\begin{array}{l}4 \\
4 \\
4\end{array}$ & $\begin{array}{r}1188.889 \\
31.752 \\
212.745\end{array}$ & $\begin{array}{r}7.643 \\
.281 \\
6.119\end{array}$ & $\begin{array}{l}.000^{*} \\
.889 \\
.000^{*}\end{array}$ \\
\hline Year + variety & $\begin{array}{l}\text { Germination (\%) } \\
\text { Virus incidence (\%) } \\
\text { Yield }\end{array}$ & $\begin{array}{r}3664.444 \\
698.990 \\
366.600\end{array}$ & $\begin{array}{l}8 \\
8 \\
8\end{array}$ & $\begin{array}{r}458.056 \\
87.374 \\
45.825\end{array}$ & $\begin{array}{r}2.945 \\
.773 \\
1.318\end{array}$ & $\begin{array}{l}.008^{*} \\
.628 \\
.252\end{array}$ \\
\hline Location + year + variety & $\begin{array}{l}\text { Germination (\%) } \\
\text { Virus incidence (\%) } \\
\text { Yield }\end{array}$ & $\begin{array}{r}11357.778 \\
337.690 \\
1304.875\end{array}$ & $\begin{array}{l}8 \\
8 \\
8\end{array}$ & $\begin{array}{r}1419.722 \\
42.211 \\
163.109\end{array}$ & $\begin{array}{r}9.127 \\
.374 \\
4.691\end{array}$ & $\begin{array}{l}.000^{*} \\
.931 \\
.000^{*}\end{array}$ \\
\hline
\end{tabular}

${ }^{*}=$ Level of significance; Yield $\left(\mathrm{kg} / 30 \mathrm{~m}^{2}\right)$

TABLE 3. Germination of Yam tubers planted in Abuja and Kwara State

\begin{tabular}{|c|c|c|c|c|c|c|}
\hline \multirow[t]{2}{*}{ Yam varieties by location } & \multirow[t]{2}{*}{$\mathrm{N}$} & \multicolumn{5}{|c|}{ Subsets } \\
\hline & & 1 & 2 & 3 & 4 & 5 \\
\hline L2V4-Orin & 9 & 44.444 & & & & \\
\hline L2V5-Elemsu & 9 & 52.222 & 52.222 & & & \\
\hline LIV4-Army & 9 & & 65.556 & 65.556 & & \\
\hline L1V3-Makakusa & 9 & & 66.667 & 66.667 & & \\
\hline L1V1-TDr 89/026665 & 9 & & 70.000 & 70.000 & & \\
\hline L1V5-Dan-anachia & 9 & & & 73.333 & 73.333 & \\
\hline L2V3-Gbakumo & 9 & & & 74.444 & 74.444 & \\
\hline L2V1-TDr 89/02665 & 9 & & & 80.000 & 80.000 & 80.000 \\
\hline L1V2-TDa 05/00129 & 9 & & & & 90.000 & 90.000 \\
\hline L2V2-TDa 05/00129 & 9 & & & & & 97.778 \\
\hline Sig. & & .944 & .096 & .313 & .148 & .096 \\
\hline
\end{tabular}

Means in the same Subsets are not significantly different $(P>0.05)$ using Tukey HSD. L = Location, L1 = Abuja, L2 = Kwara, V $=$ Variety 
Tuber yield of yam varieties. Varieties Orin and Elemsu from Kwara State recorded the lowest yield that was not significantly different from Gbakumo, TDr 89/02665 (Kwara State), TDr 89/ 02665 and Makakusa (Abuja). Variety TDa 05/ 00129 (Abuja) recorded the highest yield followed by TDa 05/00129 from Kwara State (Table 4).

Interaction of year with measured variables. Table 5 shows that the germination was lowest in year 2 . The germination in years 1 and 3 are significantly higher than in year 2 . Virus incidence between the years of trial showed significant difference between year 2 and 1 only (Table 5).
The yam tuber yield of year 2 was significantly lower than years 1 and 3 , while there was no significant difference between years 1 and 3 (Table 5).

\section{DISCUSSION}

In the first year of trial, low incidence of single infections with YMV was detected in all varieties of seed yams except Dan-anachia and Army in Abuja FCT. At the end of the third year of study, all seed tuber varieties at the two locations showed evidence of additional infection with YMMV and Badna virus either in single or mixed

TABLE 4. Tuber yield of yam varieties from Abuja and Kwara State

\begin{tabular}{|c|c|c|c|c|c|}
\hline \multirow[t]{2}{*}{ Yam varieties by location } & \multirow[t]{2}{*}{$\mathrm{N}$} & \multicolumn{4}{|c|}{ Subsets } \\
\hline & & 1 & 2 & 3 & 4 \\
\hline L2V4-Orin & 9 & 7.606 & & & \\
\hline L2V5-Elemsu & 9 & 7.839 & & & \\
\hline L2V3-Gbakumo & 9 & 11.544 & 11.544 & & \\
\hline L2V1-TDr 89/02665 & 9 & 12.622 & 12.622 & & \\
\hline L1V1-TDr 89/02665 & 9 & 13.878 & 13.878 & & \\
\hline L1V3-Makakusa & 9 & 15.700 & 15.700 & & \\
\hline LIV4-Army & 9 & & 18.644 & 18.644 & \\
\hline L1V5-Dan-anichia & 9 & & 19.489 & 19.489 & \\
\hline L2V2-TDa 05/00129 & 9 & & & 25.467 & \\
\hline L1V2-TDa 05/00129 & 9 & & & & 44.222 \\
\hline Sig. & & .125 & .141 & .314 & 1.000 \\
\hline
\end{tabular}

Means in the same Subsets are not significantly different $(P>0.05)$ using Tukey HSD. L = Location, L1 = Abuja, L2 = Kwara, $\mathrm{V}=$ Variety, $\mathrm{N}=$ Number of varieties

TABLE 5. Germination, virus incidence and yield under 3 years of study in Abuja and Kwara State

\begin{tabular}{|c|c|c|c|c|c|c|c|c|}
\hline \multicolumn{3}{|c|}{ Germination percentage } & \multicolumn{3}{|c|}{ Virus incidence } & \multicolumn{3}{|c|}{ Tuber yield } \\
\hline \multirow[t]{2}{*}{ Year } & \multicolumn{2}{|c|}{ Groups } & \multirow[t]{2}{*}{ Year } & \multicolumn{2}{|c|}{ Groups } & \multirow[t]{2}{*}{ Year } & \multicolumn{2}{|c|}{ Groups } \\
\hline & 1 & 2 & & 1 & 2 & & 1 & 2 \\
\hline 2 & 59.333 & & 1 & 63.510 & & 2 & 14.250 & \\
\hline 3 & & 74.000 & 3 & 67.040 & 67.040 & 3 & & 18.653 \\
\hline 1 & & 81.000 & 2 & & 72.010 & 1 & & 20.200 \\
\hline Sig. & 1.000 & 0.084 & Sig. & 0.408 & 0.175 & Sig. & 1.000 & 0.570 \\
\hline
\end{tabular}

Means in the same group are not significantly different $(P>0.05)$ using Tukey HSD 
form. The local yam varieties Army and Dananachia, which did not exhibit virus in them in the first year of trial, were indexed positive to virus infection in the second and third years. More viruses were detected in mixed infections in 2011 and 2012 than 2010. These findings indicate that repeated use of the seed yams resulted in increasing build-up of viruses, similar to the finding by Kenyong et al. (2001) and, Bodoni and Chanhan (2009). The study also showed similarity of high level virus presence in the yam varieties across location and years. This pattern of virus spread may be due to the usual practice by farmers who transport particularly high-yielding species from different sources to their farms for planting (Kenyong et al., 2001; Asala, 2014). The seeds would be expected to take along with them to new locations, whatever viruses inhabit them.

The study also indicated that there was interaction between locations of trial, varieties of yam used and years of study with measured variables of germination percentage, virus incidence in tuber and yield. Variety TDa 05/00129 (Dioscorea alata) which had the highest germination and yield across locations also had high incidence of mixed virus infection in seeds. The unexpected high yield suggests adaptation of this variety to prevailing conditions in the locations (Kenyong et al., 2001; Asala, 2014). The varieties Orin and Elemsu from Kwara State recorded the lowest germination, high virus incidence and lowest yield of tubers over the three years of study. A previous study (Asala, 2014), in agreement with findings by Akinlosotu (1985), Palaniswamy (1991), Kapinga et al. (2005) and Okoroafor (2009) demonstrated the presence of leaf beetles (Crioceris livida), mealy-bug (Planococcus spp.), termites (Amitermes), scale insects (Aspidiella hortii), tuber beetle (Heteroligus spp.) in association with yam in the field and at harvest. It was suggested that these insects may explain the high virus infection and correspondingly low yield of other yam varieties.

The interaction between the years of study and measured variables indicated that the first year had the highest germination, lowest virus incidence and highest tuber yield. On the contrary, the second year had lowest germination, highest virus incidence and lowest tuber yields. Climatic factors such as inconsistent rainfall, high relative humidity and temperature in 2011 at the two locations had the capacity to support increased activities of vectors and weed growth (Asala, 2014). These would in turn encourage increase in virus disease progression resulting into low yield of tubers at harvest for that year.

Degeneration of planting materials is one of the challenges faced by farmers who are involved in vegetative propagation of crops such as yam. It is therefore important in farm management that seed yams be refreshed from time to time rather than continuously planting those from the same stock. Already infected planting materials from one region should not be moved to another so as to avoid the risk of creating more devastating infections. To ensure the limitation of virus spread, proper quarantine should be in place and only virus-free germplasm or high yielding planting materials should be used. Unfortunately, these planting materials are not yet available to the Nigerian local farmer on a massive scale.

\section{ACKNOWLEDGEMENT}

Authors gratefully acknowledge partial funding of this research work by the International Institute of Tropical Agriculture, through the CGIAR Research Program on Roots, Tubers and Bananas.

\section{REFERENCES}

Akinlosotu, T. A. 1985. Studies of the yam shoot beetle, Crioceris livida Dalm (Coleoptera: Crioceridae). The Nigerian Agricultural Journal (19\&20): 190-196.

Asala, S., Alegbejo, M.D., Kashina, B.D., Banwo, O.O., Asiedu, R. and Kumar, P.L. 2012. Distribution and incidence of viruses infecting Yam (Dioscorea spp.) in Nigeria. Global Journal of Bio-Science \& Biotechnology 1 (2):163 - 167.

Asala, S.W. 2014. Distribution and characterisation of viruses infecting yams (Dioscorea spp.) in the Southern Guinea Savanna zone of Nigeria. PhD Thesis. Ahmadu Bello University Zaria, Nigeria. 147pp. 
Asala, S.W., Alegbejo, M.D., Kashina, B.D. and Banwo, O.O. 2014. Incidence and epidemiology of three viruses in various plantings of yams (Dioscorea spp.) in Guinea Savanna of Nigeria. Proceedings of the $48^{\text {th }}$ Annual Conference of the Agricultural Society of Nigeria. pp. 619 - 623.

Atiri, G.I., Winter, S. and Alabi, O.J. 2003. Yam. In: Virus and virus-like diseases of major crops in developing countries. Leobenstein, G. and Thottappilly, G. (Eds.). Kluwer, Acad Press. Dordrecht, the Netherlands. 267pp.

Bodoni, A. and Chanhan, J.S. 2009. A note on micro tuber seed production of potato: Necessitate steps for Ultara Khand Hills. Report and Opinion 1 (5): 9 - 11.

Dumont, R. and Vernier, P. 2000. Domestication of yam (D. cayenensis, $D$. rotundata) within the Bariba ethnic group in Benin. Outlook on Agriculture 29:137 - 142.

Hughes, J. d' A., Dongo, L. and Atiri, L. 1997. Viruses Infecting Cultivated yam (Dioscorea alata and D. rotundata) in Nigeria. Phytopathology 87:545.

Kapinga, R., Tumwegamire, S., Lemaga, B., Andrade, M., Mwanga, R., Mtunda, K., Ndolo, P., Nsumba, J., Agilip, S. and Serwadda, B. 2005. Development of farmer based seed systems for healthy planting materials and increased sweet potato production in East and Southern Africa. African Crop Science Conference Proceedings 7: 1169 - 1173.

Kenyong, L., Shoyinka, S.A., Hughes, J. d'A. and Odu, B.O. 2001. An overview of viruses infecting Dioscorea yam in sub-Saharan Africa. Plant virology in sub-Saharan Africa. pp. 431-438. J. d'A. Hughes and Odu, B. O. (Eds.). Proceedings of a conference organized by IITA.

Migliori, A. and Cadihac, B. 1976. Contribution to the study of virus disease of yam: Dioscorea trifida in Guadeloupe. Annals of Phytopathology 8: 73-78.

Mohammed, N. A and Terry, E. R. 1979. Virus like particles and cytoplasmic inclusions associated with disease Dioscorea rotundata Poir from Nigeria. Tropical Agriculture 56: 175 - 179.

Mumford, R.A. and Seal, S.E. 1997. Rapid single tube immunocapture RT-PCR for the detection of two yam potyviruses. Journal of Virology Methods 69: 73 - 79.

Ng, S. Y.C. 1992. Micropropagation of white yam (Dioscorea rotundata Poir). Biotechnology in Agriculture and Forestry 19:135-159.

Njukeng, A.P., Hughes, J. d'A., Atiri, G.L. and Kpo, E.J.A. 2002. Distribution of yam mosaic virus in Nigeria. $8^{\text {th }}$ International Plant Virus Epidemiology Symposium. Aschersleben. pp. 12 - 17.

Odu, B.O. 2002. Identification of resistance to yam viruses in Dioscorea species and generic analysis of resistance to yam mosaic virus in Dioscorea rotundata Poir. $\mathrm{PhD}$ Thesis, University of Ibadan, Nigeria. 183pp.

Odu, B.O., Asiedu, R., Shoyinka, S.A. and Hughes, J. d'A. 2006. Reaction of white guinea yam (Dioscorea rotundata Poir) genotypes to virus disease in four agro-ecological zones in Nigeria. Journal of Physiopathology 154: $688-693$.

Okoroafor, E. 2009. Bio-efficacy of some botanical for the control of yam beetle, Heteroligus meles Billberger (Coleoptera: Dynastidae) in Benue State, Nigeria. PhD. Dissertation. Benue State University, Makurdi, Nigeria. p. 130.

Osmond, C.B. 2006. Yam mosaic virus. International Committee on Taxonomy of virus ICTVdB description .00.057.0.01.075. Pathology 2:207-213.

Palaniswamy, M.S. 1991. Yam scale insect Aspidiella hartii CKLL and its parasitoids. Journal of Root Crops 17: 75-76.

Phillips, S., Briddon, R.W., Brunt, A.A. and Hull, R. 1999. The partial characterization of a badnavirus infecting the greater Asiatic or water yam (Dioscorea alata). Journal of Phytopathology 147: 265 - 269.

Rossell, H.V. and Thottappilly, G. 1985. Virus disease of important food crops of tropical Africa. IITA Publication Series, IITA, Ibadan, Nigeria, No. 67.

Seal, S. and Muller, E. 2007. Molecular analysis of a full-length sequence of a new yam badnavirus from Dioscorea sansibarensis. Archives of Virology 152: 819 - 825.

Thouvenel, J.C. and Fauquet, C. 1979. Yam mosaic a new Potyvirus infecting Dioscorea cayenensis in the Ivory Coast. Annals of Applied Biology 93:279-283. 